\title{
An empirical model for describing the influence of water content and concentration of sulfamethoxazole (antibiotic) in soil on the total net $\mathrm{CO}_{2}$ efflux
}

\author{
Miroslav Fér*, Radka Kodešová, Barbora Kalkušová, Aleš Klement, Antonín Nikodem \\ Czech University of Life Sciences Prague, Faculty of Agrobiology, Food and Natural Resources, Dept. of Soil Science and Soil Protection, \\ Kamýcká 129, CZ-16500 Prague 6, Czech Republic. \\ * Corresponding author. Tel.: +420 2243827 57. E-mail: mfer@af.czu.cz
}

\begin{abstract}
The aim of the study was to describe the impact of the soil water content and sulfamethoxazole, SUL, (antibiotic) concentration in soil on the net $\mathrm{CO}_{2}$ efflux. Soil samples were taken from topsoils of a Haplic Fluvisol and Haplic Chernozem. Soil samples were packed into the steel cylinders. The net $\mathrm{CO}_{2}$ efflux was measured from these soil columns after application of fresh water or SUL solution at different soil water contents. The experiments were carried out in dark at $20^{\circ} \mathrm{C}$. The trends in the net $\mathrm{CO}_{2}$ efflux varied for different treatments. While initially high values for water treatment exponentially decreased in time, values for solution treatment increased during the first 250-650 minutes and then decreased. The total net $\mathrm{CO}_{2}$ effluxes measured for 20 hours related to the soil water content followed the second order polynomial functions. The maximal values were measured for the soil water content of $0.15 \mathrm{~cm}^{3} \mathrm{~cm}^{-3}$ (Haplic Fluvisol with water or solution, Haplic Chernozem with solution) and $0.11 \mathrm{~cm}^{3} \mathrm{~cm}^{-3}$ (Haplic Chernozem with water). The ratios between values measured for solution and water at the same soil water contents exponentially increased with increasing SUL concentration in soils. This proved the increasing stimulative influence of SUL on soil microbial activity.
\end{abstract}

Keywords: Repacked soil columns; Antibiotics; Soil respiration; $\mathrm{CO}_{2}$ emission; Birch effect; $\mathrm{CO}_{2}$ efflux stimulation.

\section{INTRODUCTION}

Emission of $\mathrm{CO}_{2}$ from various sources into the atmosphere is one of the factors affecting the climate change. Vegetation and soils are important carbon pools. Soil can store a large amount of carbon. However, due to management practices soil can become also a significant source of $\mathrm{CO}_{2}$ in the atmosphere (Bahn et al., 2010; Kuzyakov, 2006). $\mathrm{A} \mathrm{CO}_{2}$ efflux from the soil surface is influenced by many abiotic and biotic factors including soil temperature, soil water content, organic carbon content, composition and activity of microbial community, etc. (Balogh et al., 2011; Buchmann, 2000; Davidson and Janssens, 2006; Davidson et al., 1998; Fér et al., 2014, 2018a; Zhong et al., 2016). The microbial activity and consequently $\mathrm{CO}_{2}$ emission can be influenced by many amendments including contaminants that can occur in the soils environment. Recently, treated wastewater is used for irrigation due to a water scarcity. Sewage sludge or farm biosolids are used as fertilizers. Nowadays, with the development of instruments and measurement accuracy, it has been found that these sources include variety of micropollutants including the human and veterinary pharmaceuticals that can contaminate soils and plants (Charuaud et al., 2019; Golovko et al., 2016; Ivanová et al., 2018; Klement et al., 2020; Kodešová et al., 2019a, b; Velicchi and Zambello, 2015). Depending on compounds and soil properties, pharmaceuticals can be strongly sorbed in the soils environment or can be highly mobile and can contaminate ground water (e.g., Fér et al., 2018b; Klement et al., 2018; Kočárek et al., 2016; Kodešová et al., 2015; Schaffer and Licha, 2015; Schmidtová et al., 2020). On one hand, their dissipation from soils is mostly driven by microbial conditions (e.g., Al-Khazray et al., 2018; Biel-Maeso et al.; 2019; Hurtado et al., 2017; Kodešová et al., 2016, 2020; Shen et al., 2018; Srinivasan and Sarmah, 2014; Zhang et al., 2017). On the other hand, pharmaceuticals and particularly antibiotics can strongly affect a microbial structure and activity (i.e., also $\mathrm{CO}_{2}$ efflux). Antibiotics can either inhibit the activity of microorganisms and consequently reduce degradation of compounds or the activity and degradation of compounds can be enhanced due to an interaction among compounds in soil solution (Caraccilo et al., 2015; Chen and Xie, 2018; Frková et al., 2020; Grenni et al., 2018; Thelusmond et al., 2019; Zhi et al., 2019).

To asses microbial conditions a basal respiration (i.e., $\mathrm{CO}_{2}$ accumulation rates) (Molaei et al., 2017) or substrate induce respiration can be measured using a small amount of a disturbed soil sample (Anderson and Domsch, 1985). $\mathrm{CO}_{2}$ accumulation rates can be also measured during the degradation experiment (OECD, 2002). However, information about an actual influence of a certain antibiotic on a $\mathrm{CO}_{2}$ emission from the surface of a larger soil samples is limited. To our knowledge, there is no study evaluating the coupled impact of antibiotic (in our case SUL) concentration in soil and soil water content on the net efflux of $\mathrm{CO}_{2}$ from the soil. Therefore, the goals of our study were a) to evaluate the effect of increasing soil water contents on the soil $\mathrm{CO}_{2}$ efflux from approximately one-kilogram soil samples packed in steel cylinders; b) to evaluate the impact of the increasing soil water content and concentration of SUL in soils on the soil $\mathrm{CO}_{2}$ efflux; and c) to propose an empirical model how to describe the influence of water content and concentration of SUL in soil on $\mathrm{CO}_{2}$ efflux.

\section{MATERIALS AND METHODS Sulfamethoxazole}

The pharmaceutically active ingredient SUL (Table 1), which is very often used in human and in veterinary medicine, was chosen for this study. SUL is a sulfonamide bacteriostatic antibiotic that is mostly used in combination with trimethoprim, 
Table 1. Sulfamethoxazole properties (https://www.drugbank.ca/) and the average parameters $\mathrm{K}_{\mathrm{F}}$ and $\mathrm{n}$ of the Freundlich sorption isotherm $\left(\mathrm{s}=\mathrm{K}_{\mathrm{F}} \mathrm{c}^{1 / \mathrm{n}}\right.$, where $\mathrm{s}$ is the concentration sorbed onto the soil particles and $\mathrm{c}$ is the concentration in soil water) and average dissipation halflife $\mathrm{DT}_{50}$ measured on 11 topsoils by Kodešová et al. $(2015,2016)$.

\begin{tabular}{|c|c|c|c|c|}
\hline CAS & Molecular structure & $\begin{array}{c}\text { MW } \\
\left(\mathrm{g} \mathrm{mol}^{-1}\right)\end{array}$ & $\begin{array}{c}\text { Solubility } \\
\left(\mathrm{mg} \mathrm{L}^{-1}\right)\end{array}$ & Log Kow \\
\hline $723-46-6$ & & 253.28 & 610 & 0.89 \\
\hline pKa & $\begin{array}{c}K_{F} \\
\left(\mathrm{~cm}^{3 / \mathbf{n}} \mu \mathrm{g}^{1-1 / \mathbf{n}} \mathrm{g}^{-1}\right)\end{array}$ & n & \multicolumn{2}{|c|}{$\begin{array}{c}\mathrm{DT}_{50} \\
\text { (days) }\end{array}$} \\
\hline $\begin{aligned} \mathrm{pKa}_{1} & =1.7 \text { (basic) } \\
\mathrm{pKa}_{2} & =5.6 \text { (acidic) }\end{aligned}$ & $2.22 \pm 1.68$ & 1.65 & \multicolumn{2}{|c|}{$7.84 \pm 3.2$} \\
\hline
\end{tabular}

Table 2. Basic soil properties: the average values and standard deviation of electric conductivity measured in water $\left(\mathrm{EC}_{\mathrm{H} 2 \mathrm{O}}\right)$ and ethanol $\left(\mathrm{EC}_{\mathrm{ET}}\right)$, active soil reaction $\left(\mathrm{pH}_{\mathrm{H} 2 \mathrm{O}}\right)$, potential soil reaction $\left(\mathrm{pH}_{\mathrm{KCl}}\right)$, oxidizable organic carbon content $(\mathrm{Cox})$, particle density $(\rho \mathrm{s})$, bulk density $\left(\rho_{\mathrm{D}}\right)$, total soil porosity $(\mathrm{P})$ and sand, silt and clay content $(\%)$ for the Haplic Fluvisol (A) and the Haplic Chernozem (B).

\begin{tabular}{|c|c|c|c|c|c|c|}
\hline & $\begin{array}{c}\text { ECH2O } \\
\left(\mu \mathrm{S} \mathrm{cm}^{-1}\right)\end{array}$ & $\begin{array}{c}\text { ECET } \\
\left(\mu \mathrm{S} \mathrm{cm}^{-1}\right)\end{array}$ & \multicolumn{2}{|c|}{$\begin{array}{c}\mathrm{pH} 2 \mathrm{O} \\
(-)\end{array}$} & $\begin{array}{c}\text { pHKCl } \\
(-)\end{array}$ & $\begin{array}{c}\text { Cox } \\
(\%)\end{array}$ \\
\hline $\mathrm{A}$ & $100.1 \pm 1.2$ & $2.7 \pm 0.10$ & \multicolumn{2}{|c|}{$7.06 \pm 0.02$} & $5.88 \pm 0.05$ & $1.62 \pm 0.01$ \\
$\mathrm{~B}$ & $119.1 \pm 0.4$ & $3.5 \pm 0.2$ & \multicolumn{2}{|c|}{$8.16 \pm 0.03$} & $7.21 \pm 0.01$ & $1.79 \pm 0.01$ \\
\hline & $\begin{array}{c}\rho_{\mathrm{s}} \\
\left(\mathrm{g} \mathrm{cm}^{-3}\right)\end{array}$ & $\begin{array}{c}\rho_{\mathrm{d}} \\
\left(\mathrm{g} \mathrm{cm}^{-3}\right)\end{array}$ & $\begin{array}{c}\mathrm{P} \\
(\%)\end{array}$ & $\begin{array}{c}\text { Sand } \\
(\%)\end{array}$ & $\begin{array}{c}\text { Silt } \\
(\%)\end{array}$ & $\begin{array}{c}\text { Clay } \\
(\%)\end{array}$ \\
\hline $\mathrm{A}$ & $2.58 \pm 0.01$ & $1.43 \pm 0.06$ & $46.2 \pm 0.02$ & 69.0 & 19.2 & 11.8 \\
$\mathrm{~B}$ & $2.52 \pm 0.01$ & $1.39 \pm 0.05$ & $47.4 \pm 0.02$ & 5.4 & 58.1 & 36.5 \\
\hline
\end{tabular}

which is an antifolate antibacterial agent. SUL is highly mobile in the soil-water environment, because its sorption on soil constituents is low (i.e., low Freundlich $\mathrm{K}_{\mathrm{F}}$ coefficients in Table 1). Its stability in soils is also relatively low (i.e., low dissipation half-life, $\mathrm{DT}_{50}$ in Table 1). Its dissipation in soils is mainly due to biodegradation under aerobic conditions and can be significantly affected by its initial concentration in soils (Shen et al., 2018; Srinivasan and Sarmah, 2014). This means that there is a strong interaction between SUL and microbial community that should largely affect $\mathrm{CO}_{2}$ effluxes from soils. SUL was purchased from BDL Czech Republic Ltd. (Turnov, Czech Republic), and has $98 \%$ analytical grade purity. Compound $(2 \mathrm{mg})$ was dissolved in fresh water $(2 \mathrm{~L})$. The actual concentrations in the applied solution were analyzed using the normal injection LC-MS/MS method, described by Golovko et al. (2016). The intended concentration was $0.1 \mu \mathrm{g} \mathrm{mL}^{-1}$ and measured concentration was $0.097 \mu \mathrm{g} \mathrm{mL} \mathrm{m}^{-1}$.

\section{Study sites, soil sampling and basic soil properties}

The study was performed on the soil samples collected from two experimental research stations of the Czech University of Life Sciences Prague in the Czech Republic. The research station A is in Prague-Troja, $\left(50.122^{\circ} \mathrm{N}, 14.399^{\circ} \mathrm{E}\right)$ and $\mathrm{B}$ is in Prague-Suchdol $\left(50.128^{\circ} \mathrm{N}, 14.374^{\circ} \mathrm{E}\right)$. The soil type in the area of the Prague-Troja research station was defined as the Haplic Fluvisol developed on sediments of river Vltava and soil type in Prague-Suchdol was described as the Haplic Chernozem on loess (WRB, 2015). The soil samples (10 kg of disturbed soil from each location) were taken in March 2018 from the depth of $0-8 \mathrm{~cm}$ of the bare soils at 3 spots and transported within one day to the laboratory. Parts of the grab soil samples, which were next used to determine basic soil properties, were air-dried and sieved through a 2-mm mesh. The basic chemical and physical properties (Table 2) were determined using standardized laboratory techniques: active soil reaction $\left(\mathrm{pH}_{\mathrm{H} 2 \mathrm{O}}\right)$ and potential soil reaction $\left(\mathrm{pH}_{\mathrm{KCl}}\right)$ (ISO 10390, 2005), salinity (EC) (Rhoades, 1996), oxidizable organic carbon content (Cox) (Skjemstad and Baldock, 2008), particle size distribution (Gee and Or, 2002) and particle density ( $\rho$ s) (Flint and Flint, 2002). Additional information about soil properties of studied soils were published by Pavlů et al. (2021) for A location and by Kodešová et al. (2015, 2016, 2019a, b, 2020) and Klement et al. (2020) for B location.

Parts of soil samples intended for the laboratory measurement of the net $\mathrm{CO}_{2}$ and water $\left(\mathrm{H}_{2} \mathrm{O}\right)$ effluxes from soils were also air-dried. The soil was homogenised and aggregates with a diameter of larger than $1 \mathrm{~cm}$ were extracted using a $10-\mathrm{mm}$ mesh. This treatment of the material preserved the natural aggregation of the soil and at the same time it was possible to pack the material into the $665 \mathrm{~cm}^{3}$ steel cylinders so that the bulk density of the naturally consolidated soil was achieved. The bulk densities and porosities of the naturally consolidated soils (Table 2) were measured on the $100 \mathrm{~cm}^{3}$ undisturbed soil cores (Dane and Topp, 2002), which were taken in four replicates on the both experimental plots.

\section{Experimental setup for measuring net $\mathrm{CO}_{2}$ and $\mathrm{H}_{2} \mathrm{O}$ effluxes from the soil sample surface}

Two experiments were performed for each soil. The first set of experiments (A1 and B1) was carried out with fresh water and the second set of experiments was carried out with SUL solution (SUL dissolved in fresh water). The experiment for each soil and treatment lasted 6 days. At the beginning of each experiment the air-dried soil (989 and $855 \mathrm{~g}$ for A and B, re- 
spectively) was packed into the $665 \mathrm{~cm}^{3}$ steel cylinder (diameter of $11 \mathrm{~cm}$ and height of $7 \mathrm{~cm}$ ) and then the net $\mathrm{CO}_{2}$ and net $\mathrm{H}_{2} \mathrm{O}$ effluxes were measured in one minute interval for 20 hours using the LCi-SD portable photosynthesis system with a Soil Respiration Chamber (that is described below). Next, the soil was spread into the tray, wetted using the sprayer, mixed and packed back into the cylinder, and measurements of the net $\mathrm{CO}_{2}$ and net $\mathrm{H}_{2} \mathrm{O}$ efflux were repeated again for 20 hours. This procedure was recurred several times as long as it was possible to treat the soil without destroying its structure. Five wetting steps were set for both soils. The intended volumetric soil water $(\theta)$ contents for A samples were 0.02 (air-dried soils), 0.06, $0.11,0.15,0.19$ and $0.24 \mathrm{~cm}^{3} \mathrm{~cm}^{-3}$, and for B samples were 0.02 (air-dried soils), 0.07, 0.11, 0.14, 0.17 and $0.21 \mathrm{~cm}^{3} \mathrm{~cm}^{-3}$. The actual volumetric soil water content was checked gravimetrically.

The net $\mathrm{CO}_{2}$ and net $\mathrm{H}_{2} \mathrm{O}$ efflux were measured using the LCi-SD portable photosynthesis system with a Soil Respiration Chamber, according to Instruction Manual to Soil Respiration Hood V2 (ADC BioScientific, 2011). Two main components of soil respiration were measured: the net $\mathrm{CO}_{2}$ efflux (NCER) and the net $\mathrm{H}_{2} \mathrm{O}$ efflux $\left(W_{f l u x}\right)$. Soil $\mathrm{CO}_{2}$ emission (net molar flow of $\mathrm{CO}_{2}$ in/out of the soil $\left(p \mathrm{~mol} \mathrm{~s}^{-1}\right)$ is characterized as

$C=u(-\Delta c)$

where $u$ is molar air flow in mol s${ }^{-1} ; \Delta c$ is the difference in $\mathrm{CO}_{2}$ concentration through the soil chamber, $\left(\mu \mathrm{mol} \mathrm{mol}{ }^{-1}\right)$

$\Delta c=C_{r e f}-C_{a n}$

where $C_{r e f}$ is the $\mathrm{CO}_{2}$ flowing into the soil chamber $\left(\mu \mathrm{mol} \mathrm{mol}{ }^{-1}\right)$, $C_{a n}$ is $\mathrm{CO}_{2}$ flowing out from the soil chamber $\left(\mu \mathrm{mol} \mathrm{mol}{ }^{-1}\right)$.

The net $\mathrm{CO}_{2}$ efflux ( $C_{e}$ per unit area) symbol NCER $\left(\mu \mathrm{mol} \mathrm{s}{ }^{-1} \mathrm{~m}^{-2}\right)$ is described as:

$N C E R=u_{s}(-\Delta c)$

where $u_{s}$ is the molar flow of air per square metre of soil, mol m${ }^{-2} \mathrm{~s}^{-1} ; \Delta c$ is the difference in $\mathrm{CO}_{2}$ concentration through soil hood, $\mu \mathrm{mol} \mathrm{mol}{ }^{-1}$.

The net $\mathrm{H}_{2} \mathrm{O}$ flux (water flux) $W_{f l u x}\left(\mathrm{mmol} \mathrm{s}^{-1} \mathrm{~m}^{-2}\right)$ is characterized as:

$W_{f l u x}=\Delta e u_{s} / p$

where $u_{s}$ is the molar flow of air per square metre of soil, mol $\mathrm{m}^{-2} \mathrm{~s}^{-1} ; \Delta e$ is the differential water vapour concentration, $\mathrm{m}$ Bar; and $p$ is the atmospheric pressure, mBar.

To avoid the influence of variable solar radiation (e.g., Fér et al., 2018a) and temperature (Schaufler et al., 2010; Yueste et al., 2007) on the measured values, the net $\mathrm{CO}_{2}$ and net $\mathrm{H}_{2} \mathrm{O}$ effluxes were measured in the dark and at $20^{\circ} \mathrm{C}$ in a growth chamber (KBF 240, Binder, Germany). The air humidity varied between 30 and $40 \%$.

Next, the soil $\mathrm{CO}_{2}$ efflux data was analyzed with the $\mathrm{R}$ software (R Development Core Team, 2015) to eliminate error measurements. This procedure, which was in detailed described by Fér et al. (2018a), includes the smoothing using the Savitzky-Golay filter to reduce the most urgent misleading records caused by the repeated disruption of the measurement conditions and the reconstruction of the potential unaffected course of the measurement by computing its continuum.

\section{Data evaluation}

Since the main aim of this study was the evaluation of the coupled impact of the antibiotic SUL and soil water content on the $\mathrm{CO}_{2}$ emission from the soils, the analyses mainly focused on the net $\mathrm{CO}_{2}$ efflux data. The initial, maximal and final values of the net $\mathrm{CO}_{2}$ efflux were expressed for each treatment and related to the water content steps. The cumulative net $\mathrm{CO}_{2}$ efflux and the total net $\mathrm{CO}_{2}$ efflux for 20 hours were evaluated. The values of the total net $\mathrm{CO}_{2}$ efflux for the water treatment were related to the soil water contents. To assess an influence of the SUL content in soils on the $\mathrm{CO}_{2}$ emission, the ratios between the values of the total net $\mathrm{CO}_{2}$ efflux for the SUL solution treatment were divided by the values of the total net $\mathrm{CO}_{2}$ efflux for the water treatment only at the same soil water content. These ratios were next related to the SUL concentrations in soils expressed as follows:

$s_{i}=\sum_{i=0}^{N}\left(V_{i} c\right) / m$

where $\mathrm{s}_{\mathrm{i}}$ is the concentration of SUL in soil $\left(\mu \mathrm{g} \mathrm{g}^{-1}\right), \mathrm{V}_{\mathrm{i}}$ is the volume of the applied solution $(\mathrm{mL})$, $\mathrm{c}$ is the concentration of SUL in the solution $\left(\mu \mathrm{g} \mathrm{mL} \mathrm{m}^{-1}\right), \mathrm{m}$ is the dry mass of the soil column $(\mathrm{g})$, and $\mathrm{N}$ is the number of wetting steps.

The net $\mathrm{H}_{2} \mathrm{O}$ efflux depended on the actual soil water content, but no influence of SUL on the net $\mathrm{H}_{2} \mathrm{O}$ efflux was observed. This data is not further discussed in this paper.

\section{RESULTS AND DISCUSSION}

The trends of the net $\mathrm{CO}_{2}$ effluxes for particular soil water contents considerably differed for different treatments (i.e., for fresh water and SUL solution). In the case of fresh water and A1 soil sample (Haplic Fluvisol), the initially high net $\mathrm{CO}_{2}$ efflux exponentially decreased in time for all soil water contents (Fig 1a). The similar trends in the net $\mathrm{CO}_{2}$ effluxes were observed for B1 soil samples (Haplic Chernozem) of soil water contents of 0.07 and $0.21 \mathrm{~cm}^{3} \mathrm{~cm}^{-3}$ (Fig 1c). For other soil water contents, the net $\mathrm{CO}_{2}$ efflux initially increased (rise time varied between 250 and $300 \mathrm{~min}$ ) and then declined. The range of the net $\mathrm{CO}_{2}$ efflux was similar $\left(0-2 \mu \mathrm{mol} \mathrm{s}{ }^{-1} \mathrm{~m}^{-2}\right)$ for both soil sample (A1 and B1). The very high soil respiration in the beginning after rewetting and then decrease in soil respiration is called the respiration pulse or the Birch effect (Birch, 1958), which was also find in our previous study where undisturbed soil samples were wetted by a capillary rise from the bottom of the soil samples (Fér et al., 2018a). The similar results were obtained by Iovieno and Bååth (2008), who demonstrated almost no respiration on the air-dried soil samples and exponential decrease of soil respiration after rewetting to $60 \%$ of water holding capacity (WHC). The exponential decrease in soil respiration was observed after rewetting $(50 \%$ of WHC) soil samples after 4 days of air-drying by Meisner et al. $(2013 ;$ 2015).

In the case of SUL solution, the net $\mathrm{CO}_{2}$ effluxes measured on the A2 and B2 samples of soil water contents of 0.02 (A2 and B2), 0.06 (A2) and 0.07 (B2) $\mathrm{cm}^{3} \mathrm{~cm}^{-3}$ (Figure $1 \mathrm{~b}$ and $1 \mathrm{~d}$ ) were similar to those measured for $\mathrm{A} 1$ and $\mathrm{B} 1$ samples of the same soil water contents (Figure 1a and 1c). This similarity can be explained by relatively low SUL amounts in soil samples (i.e., low concentrations of SUL in soils, expensed as weight of SUL per unit weight of dry soil) and thus likely a low influence on a microbial community. On the other hand, the trends in the 


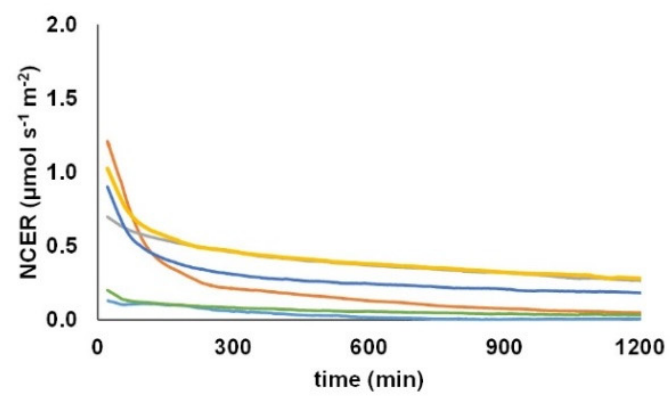

a)

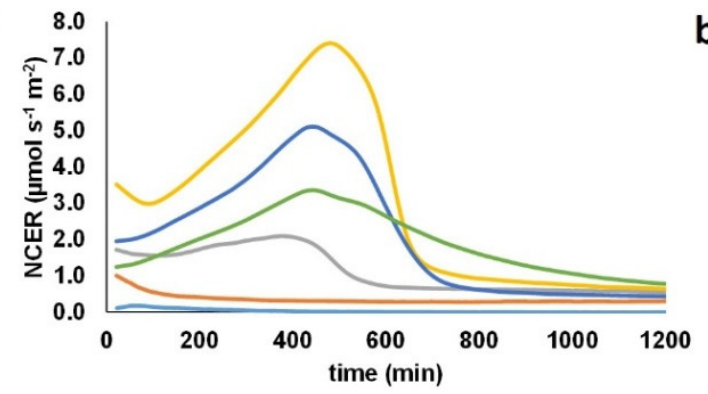

b)

$\theta\left(\mathrm{cm}^{3} \mathrm{~cm}^{-3}\right)-0.02-0.06-0.11-0.15-0.19-0.24$



c)

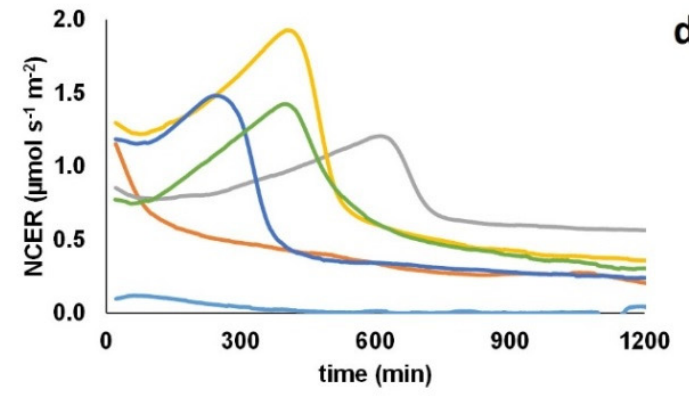

d)

$\theta\left(\mathrm{cm}^{3} \mathrm{~cm}^{-3}\right)-0.02-0.07-0.11-0.14-0.17-0.21$

Fig. 1. Recorded net $\mathrm{CO}_{2}$ effluxes (NCER) for 20 hours: (a) and (b) are A1 and A2 soil samples from the Haplic Fluvisol wetted with fresh water and SUL solution, respectively, and (c) and (d) are B1 and B2 soil samples from the Haplic Chernozem wetted with fresh water and SUL solution, respectively.


b)

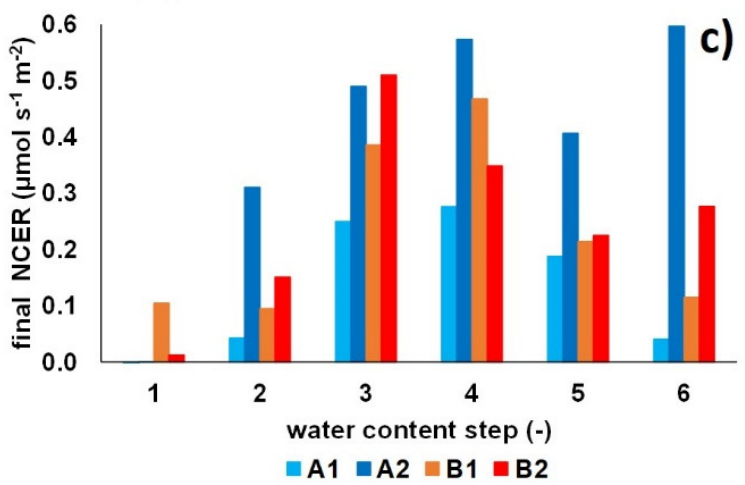

Fig. 2. Initial (a), maximal (b) and final (c) values of the net $\mathrm{CO}_{2}$ effluxes (NCER): $\mathrm{A} 1$ is the soil sample from the Haplic Fluvisol wetted with fresh water, A2 is the soil sample from the Haplic Fluvisol wetted with SUL solution, B1 is the soil sample from the Haplic Chernozem wetted with fresh water and B2 is the soil sample from the Haplic Chernozem wetted with SUL solution.

net $\mathrm{CO}_{2}$ effluxes for higher soil water contents and therefore also higher SUL concentrations in both soil samples (A2 and B2) completely differed from those wetted with fresh water (A1 and $\mathrm{B} 1)$. The net $\mathrm{CO}_{2}$ efflux increased during the first 450 minutes for A2 and 250-650 minutes for B2 (when the maximal net $\mathrm{CO}_{2}$ efflux was reached) and next decreased (Fig. 1b and 1d). The trends in the initial and maximal values of the net
$\mathrm{CO}_{2}$ effluxes evaluated for particular soil samples were similar (Figure $2 \mathrm{a}$ and $2 \mathrm{~b}$ ). Values mostly initially increased with wetting and then declined. The final values of the net $\mathrm{CO}_{2}$ effluxes for $\mathrm{A} 1$ and $\mathrm{B} 1$ also initially increased and then decreased with increasing wetting. However, in the case of A2 and B2, the final values initially increased and then values varied between $(0.4$ 0.6 and $0.25-0.35 \mu \mathrm{mol} \mathrm{s}^{-1} \mathrm{~m}^{-2}$, for A2 and B2, respectively). 
The cumulative net $\mathrm{CO}_{2}$ effluxes from the soil samples (Figure $3 \mathrm{a}$ and $3 \mathrm{c}$ ) even better showed the effect of an increasing soil water content on the net $\mathrm{CO}_{2}$ efflux. The total net $\mathrm{CO}_{2}$ efflux (Figure 3a) increased up to the soil water content of 0.15 $\mathrm{cm}^{3} \mathrm{~cm}^{-3}$ (A1) and $0.11 \mathrm{~cm}^{3} \mathrm{~cm}^{-3}$ (B1) and then decreased. The results confirm the fact, that with an increasing soil water content the net $\mathrm{CO}_{2}$ efflux is also increasing (Fér et al., 2018a; Moayano et al., 2018) due to improving conditions for aerobic microbes. During a further soil wetting, the soil pores are gradually filled with water, which aggravates conditions for aerobic microbes, and thus the flow of soil gas (i.e., also $\mathrm{CO}_{2}$ ) is reduced (Fér et al., 2018a). Later on, the net $\mathrm{CO}_{2}$ efflux is restricted even more due to anaerobic conditions that suppress the aerobic microbial activity (Moayano et al., 2012 or Xu et al., 2004). The similar soil water contents $\left(0.09-0.17 \mathrm{~cm}^{3} \mathrm{~cm}^{-3}\right)$ related to the highest net $\mathrm{CO}_{2}$ efflux were presented in our previous study (Fér et al., 2018a), in which the net $\mathrm{CO}_{2}$ efflux from the undisturbed soil samples collected from loess derived soils was measured using the same devise. The higher soil water contents $\left(0.20\right.$ and $\left.0.18 \mathrm{~cm}^{3} \mathrm{~cm}^{-3}\right)$ related to the highest net $\mathrm{CO}_{2}$ efflux were documented by Yueste et al. (2007) and Jiang et al. (2015) for a Chromic Cambisol and Haplic Kastanozem, respectively. One of the reasons could be that a different equipment was used to measure the $\mathrm{CO}_{2}$ efflux and/or both experiments were performed in the field conditions with undisturbed soils.

The cumulative net $\mathrm{CO}_{2}$ effluxes from the soil samples wetted with SUL solution (Figure $3 \mathrm{~b}$ and $3 \mathrm{~d}$ ) showed much steeper initial increases. The values of the total $\mathrm{CO}_{2}$ effluxes from the soil samples wetted with SUL solution are considerably and slightly higher than those for samples wetted with fresh water (Figure 3a and 3c) for the Haplic Fluvisol and Haplic Chernozem, respectively. The reason of a higher influence of SUL on the net $\mathrm{CO}_{2}$ effluxes from the Haplic Fluvisol than that from the
Haplic Chernozem could be a different influence of SUL on the soil microbial community. For instance, Frková et al. (2020) showed that SUL had a short-term stress effect on a microbial community in an Arenosol Epieutric (sandy soil that is the most similar to the Haplic Fluvisol) and the same Haplic Chernozem, which resulted in an increase in a basal respiration. This affect was more pronounced in the Arenosol Epieutric than in the Haplic Chernozem. However, the cumulative net $\mathrm{CO}_{2}$ effluxes resulted from both treatments (Figure 4a) showed similar trends and the highest total net $\mathrm{CO}_{2}$ efflux was measured at the $4^{\text {th }}$ water content step for both soils (soil-water content of $0.15 \mathrm{~cm}^{3}$ $\mathrm{cm}^{-3}$ and $0.14 \mathrm{~cm}^{3} \mathrm{~cm}^{-3}$ respectively).

Calculated ratios between the total net $\mathrm{CO}_{2}$ effluxes for samples wetted with SUL solution (A2 and B2) and fresh water (A1 and B1) exponentially increased with the increasing wetting (Figure 4b). This means that despite the soil water content largely controlled and at high values considerably restricted the net $\mathrm{CO}_{2}$ efflux, the increasing SUL concentration in soils gradually increases the net $\mathrm{CO}_{2}$ efflux.

The data points given by the water contents and the related total net $\mathrm{CO}_{2}$ efflux for water treatments (A1 and $\left.\mathrm{B} 1\right)$ were fitted with the polynomial functions (Figure 4c). The intercepts of these two functions with $\mathrm{x}$-axis were 0.0189 and $0.0183 \mathrm{~cm}^{3}$ $\mathrm{cm}^{-3}$ for $\mathrm{A} 1$ and $\mathrm{B} 1$, respectively, which can be assumed as bottom limits of the soil-water contents, for which and below these values no $\mathrm{CO}_{2}$ efflux would be measured.

The data points given by the SUL concentrations in soils and rations between the total net $\mathrm{CO}_{2}$ effluxes for the samples wetted with SUL solution (A2 and B2) and fresh water (A1 and B1) were fitted with the exponential functions (Figure 4d). These equations expressed the impact of the SUL concentrations in soils under the setup experimental conditions. The calculated values of the ratios can be further considered as the multiplication coefficients with the help of which it would be

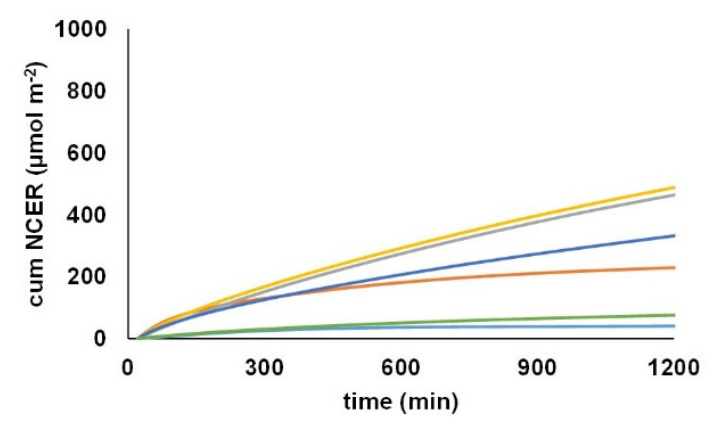

a)


c)

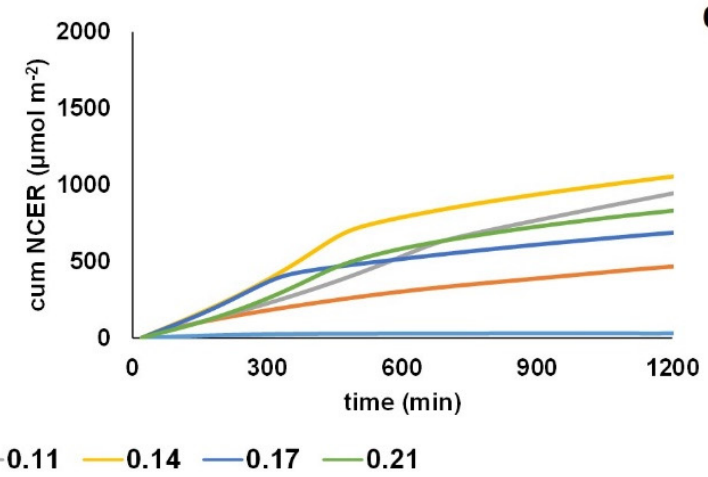

b)

d)

Fig. 3. Cumulative net soil $\mathrm{CO}_{2}$ efflux (cum NCER) recorded for 20 hours: (a) and (b) are A1 and A2 soil samples from the Haplic Fluvisol wetted with fresh water and SUL solution, respectively, and (c) and (d) are B1 and B2 soil sample from the Haplic Chernozem wetted with fresh water and SUL solution, respectively. 

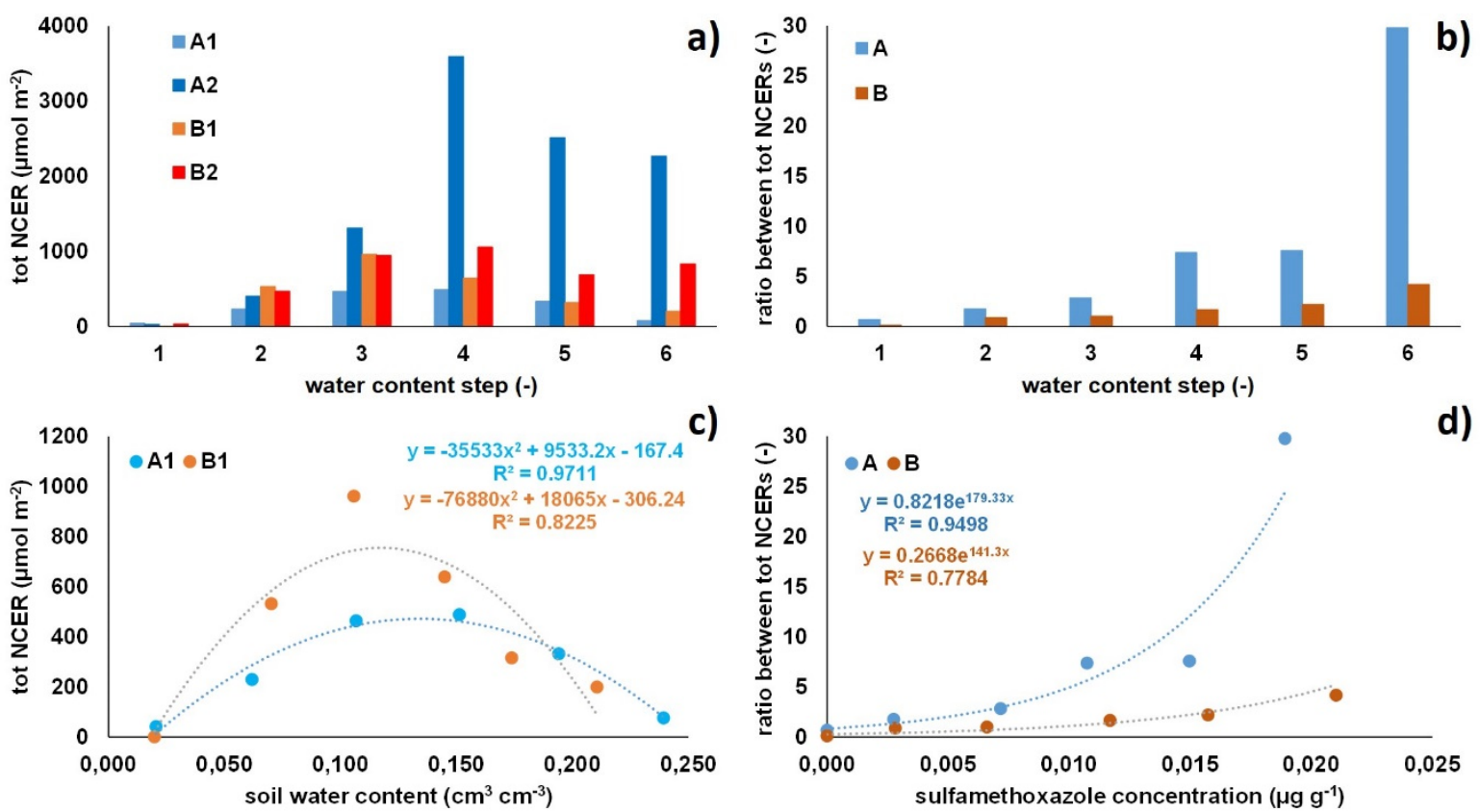

Fig. 4. The total net $\mathrm{CO}_{2}$ efflux (tot NCER) measured for 20 hours (a), the ratio between the total net $\mathrm{CO}_{2}$ effluxes for the SUL solution treatment and the water treatment (b), the relationship between the total net $\mathrm{CO}_{2}$ effluxes (tot NCER) and the soil water contents (c), the relationship between the ratio of total net $\mathrm{CO}_{2}$ effluxes and the SUL concentrations in soils, which was calculated using Eq. 5 (d): A1 is the sample from the Haplic Fluvisol wetted with water, A2 is the soil sample from the Haplic Fluvisol wetted with SUL solution, B1 is the soil sample from the Haplic Chernozem wetted with water and B2 is the soil sample from the Haplic Chernozem wetted with SUL solution.

possible to predict the values of the total net $\mathrm{CO}_{2}$ effluxes for certain SUL concentrations from the values of the total net $\mathrm{CO}_{2}$ effluxes evaluated for the water treatment. However, at this moment results cannot be generalized for different solution concentrations. One of the reasons is that the SUL concentration in soil at each wetting step was calculated as a sum of volumes of solution that were cumulatively applied into soil multiplied by the SUL concentration in solution divided by the mass of soil, and no SUL dissipation in soil was assumed. The average dissipation half-life (Table 1) indicates a relatively high dissipation rate in soils. The first order kinetic equations and reaction constant derived from the $\mathrm{DT}_{50}$ values could be used to calculate a possible decrease of SUL in each dose. Values in Table 1 were obtained at the same temperature $\left(20^{\circ} \mathrm{C}\right)$ but at the optimal soil water contents that corresponded to the field water capacities. Dissipation of SUL under dry conditions would be much slower. In addition, there could be some SUL losses during the treatments. For a better definition of soil conditions, the actual SUL concentrations in soils should be determined at each wetting step. Another reason is that experiments were carried out with solution of one SUL concentration. Similar sets of experiments should be carried out with wider range of concentrations and a possibility to generalize this empirical model for variable soil water contents and actual concentrations in soils should be investigated.

\section{CONCLUSION}

Results of this study showed that under the established experimental conditions the relationships between the total net $\mathrm{CO}_{2}$ effluxes from two soils recorded for 20 hours and the soilwater content could be approximately described using the second order polynomial functions. The antibiotic SUL considerably increased the net $\mathrm{CO}_{2}$ efflux from soils. The values of the total net $\mathrm{CO}_{2}$ efflux measured for the SUL solution treatment were several times higher than those for the water treatment and this impact increased with the increasing SUL concentrations in soils. Further studies are needed to test the proposed empirical exponential model for estimating the multiplication coefficient from the SUL concentrations in soils for wider range of SUL concentrations in applied solutions. Nevertheless, results indicated a very progressive positive impact of SUL amount in soils on undesirable $\mathrm{CO}_{2}$ emissions from the soil environment.

Acknowledgement. Authors acknowledge the financial support from the Czech Science Foundation (project No. 17-08937S) and the European Regional Development Fund-Project Centre for the investigation of synthesis and transformation of nutritional substances in the food chain in interaction with potentially harmful substances of anthropogenic origin: comprehensive assessment of soil contamination risks for the quality of agricultural products (No. CZ.02.1.01/0.0/0.0/16_019/0000845). Authors also thank to Radim Vašát for data treatment using $\mathrm{R}$ code and colleagues from University of South Bohemia in České Budějovice (Faculty of Fisheries and Protection of Waters) for measurement of SUL concentration in applied solution.

\section{REFERENCES}

ADC BioScientific, 2011. User manual LCi-SD Leaf Chamber/Soil Respiration Analysis System. Hertfortshire.

Al-Khazrajy, O.S.A., Bergstrom, E., Boxall, A.B.A., 2018. Factors affecting the dissipation of pharmaceuticals in freshwater sediments. Environ. Toxicol. Chem., 37, 3, 829-838.

Anderson, T.H., Domsch, K.H., 1985. Determination of ecophysiological maintenance carbon requirements of soil microorganisms in a dormant state. Biol. Fert. Soils., 1, 81-89.

Bahn, M., Reichstein, M., Davidson, E.A., Grünzweig, J., Jung, M., Carbone, M. S., Epron, D., Misson, L., Nouvellon, Y., Roupsard, O., Savage, K., Trumbore, S. E., Gimeno, C., 
Curiel Yuste, J., Tang, J., Vargas, R., and Janssens, I. A., 2010. Soil respiration at mean annual temperature predicts annual total across vegetation types and biomes. Biogeosciences, 7, 2147-2157.

Balogh, J., Pintér, K., Fóti, S., Cserhalmi, D., Papp, M., Nagy, Z., 2011. Dependence of soil respiration on soil moisture, clay content, soil organic matter and $\mathrm{CO}_{2}$ uptake in dry grasslands. Soil Biol. Biochem., 43, 1006-1013.

Biel-Maeso, M., González-González, C., Lara-Martín, P.A., Corada-Fernández, C., 2019. Sorption and degradation of contaminants of emerging concern in soils under aerobic and anaerobic conditions. Sci. Total Environ., 666, 662-671.

Birch, H., 1958. The effect of soil drying on humus decomposition and nitrogen availability. Plant Soil, 10, 9-31.

Buchmann, N., 2000. Biotic and abiotic factors controlling soil respiration rates in Picea abies stands. Soil Biol. Biochem., 32, 1625-1635.

Caracciolo, A.B., Topp, E., Grenni, P., 2015. Pharmaceuticals in the environment: biodegradation and effects on natural microbial communities. A review. J. Pharmaceut. Biomed., 106, 25-36.

Charuaud, L., Jardem E., Jaffrezic, A., Thomas, M.F., Le Bot, B., 2019. Veterinary pharmaceutical residues from natural water to tap water: Sales, occurrence and fate. J. Hazard. Mater., 361, 169-186.

Chen, J., Xie, S., 2018. Overview of sulfonamide biodedegradation and relevant pathways and microorganisms. Sci. Total Environ., 640-641, 1465-1477.

Davidson, E.A., Janssens, I., 2006. Temperature sensitivity of soil carbon decomposition and feedbacks to climate change. Nature, 440, 165-173.

Dane, J.H., Topp, C.T. (Eds), 2002. Methods of Soil Analysis. Part 4 - Physical Methods. Soil Science Society of America, Inc. Madison, USA.

Davidson, E.A., Belk, E., Boone, R., 1998. Soil water content and temperature as independent or confounded factors controlling soil respiration in a temperate mixed hardwood forest. Glob. Change Biol., 4, 217-227.

Fér, M., Kodešová, R., Klement, A., 2014. $\mathrm{CO}_{2}$ emission from erosion affected soils. In: 14th International Multidisciplinary Scientific Geoconference and EXPO, SGEM 2014. Albena. Bulgaria; 17 June 2014 through 26 June 2014, 2, 3, $37-44$.

Fér, M., Kodešová, R., Nikodem, A., Jelenová, K., Klement, A., 2018a. Influence of soil-water content on $\mathrm{CO}_{2}$ efflux within the elevation transect heavily impacted by erosion. Ecohydrology, 2018; e1989.

Fér, M., Kodešová, R., Golovko, O., Schmidtová, Z., Klement, A., Kočárek, M., Grabic, R., 2018b. Sorption of atenolol, sulfamethoxazole and carbamazepine onto soil aggregates from the illuvial horizon of the Haplic Luvisol on loess. Soil Water Res., 13, 3, 177-183.

Flint A.L., Flint L.E., 2002. Particle density, in. J.H. Dane, G.C. Topp (Eds.), Methods of Soil Analysis. Part 4. Physical Methods, Soil Science Society of America, Inc., Madison, USA, pp. 229-240.

Frková, Z., Vystavna, Y., Koubová, A., Kotas, P., Grabicová, K., Grabic, R., Kodešová, R., Chroňáková, A., 2020. Microbial responses to selected pharmaceuticals 1 in agricultural soils: Microcosm study on the roles of soil, treatment and time. Soil Biol. Biochem., 149, 107924.

Gee, G.W., Or, D., 2002. Particle-size analysis, in. J.H. Dane, G.C. Topp (Eds.), Methods of Soil Analysis. Part 4. Physical Methods, Soil Science Society of America, Inc., Madison, USA, pp. 255-294.
Golovko, O., Koba, O., Kodešová, R., Fedorova, G., Kumar, V., Grabic, R., 2016. Development of fast and robust multiresidual LC-MS/MS method for determination of pharmaceuticals in soils. Environ. Sci. Pollut. R., 23, 14, 14068-14077.

Grenni, P., Ancona, V., Caracciolo, A.B., 2018. Ecological effects of antibiotics on natural ecosystems: A review. Microch. J., 136, 25-39.

Hurtado, C., Montano-Chávez, Y.N., Domínguez, C., Bayona, J.M., 2017. Degradation of emerging organic contaminants in an agricultural soil: Decoupling biotic and abiotic processes. Water Air Soil Poll., 228, 243.

Iovieno, P., Bååth, E., 2008. Effect of drying and rewetting on bacterial rates in soil. FEMS Microbiol. Ecol., 65, 400-407.

ISO 10390, 2005. Soil quality-determination of pH. International Organization for Standardization, Geneva.

Ivanová, L., Mackul'ak, T., Grabic, R., Golovko, O., Koba, O., Vojs Staňová, A., Szabová, P., Grenčíková, A., Bodík, I., 2018. Pharmaceuticals and illicit drugs - a new threat to the application of sewage sludge in agriculture. Sci. Total Environ., 634, 606-615.

Jiang, J., Guo, S., Zhang, Y., Liu, Q., Wang, R., Wang, Z., Li, N., Li, R., 2015. Changes in temperature sensitivity of soil respiration in the phase of a three-year crop rotation system. Soil Till. Res., 150, 139-146.

Klement, A., Kodešová, R., Bauerová, M., Golovko, O., Kočárek, M., Fér, M., Koba, O., Nikodem, A., Grabic, R., 2018. Sorption of citalopram, irbesartan and fexofenadine in soils: estimation of sorption coefficients from soil properties. Chemosphere, 195, 615-623.

Klement, A., Kodešová, R., Golovko, O., Fér, M., Nikodem, A., Kočárek, M., Grabic, R., 2020. Uptake, translocation and transformation of three pharmaceuticals in green pea plants. J. Hydrol. Hydromech., 68, 1, 1-11.

Kočárek, M., Kodešová, R., Vondráčková, L., Golovko, O., Fér, M., Klement, A., Nikodem, A., Jakšík, O., Grabic, R., 2016. Simultaneous sorption of four ionizable pharmaceuticals in different horizons of three soil types. Environ. Pollut., 218, 563-573.

Kodešová, R., Grabic, R., Kočárek, M., Klement, A., Golovko, O., Fér, M., Nikodem, A., Jakšík, O., 2015. Pharmaceuticals' sorptions relative to properties of thirteen different soils. Sci. Total Environ., 511, 435-443.

Kodešová, R., Kočárek, M., Klement, A., Golovko, O., Koba, O., Fér, M., Nikodem, A., Vondráčková, L., Jakšík, O., Grabic, R., 2016. An analysis of the dissipation of pharmaceuticals under thirteen different soil conditions. Sci. Total Environ., 544, 369-381.

Kodešová, R., Klement, A., Golovko, O., Fér, M., Nikodem, A., Kočárek, M., Grabic, R., 2019a. Root uptake of atenolol, sulfamethoxazole and carbamazepine, and their transformation in three soils and four plants. Environ. Sci. Pollut. Res., 26, 10, 9876-9891.

Kodešová, R., Klement, A., Golovko, O., Fér, M., Kočárek, M., Nikodem, A., Grabic, R., 2019b. Soil influences on uptake and transfer of pharmaceuticals from sewage sludge amended soils to spinach. J. Environ. Manage., 250, 109407.

Kodešová, R., Chroňáková, A., Grabicová, K., Kočárek, M., Schmidtová, Z., Frková, Z., Vojs-Staňová, A., Nikodem, A., Klement, A., Fér, M., Grabic, R., 2020. How microbial community composition, sorption and simultaneous application of six pharmaceuticals affect their dissipation in soils. Sci. Total Environ., 746, 141134.

Kuzyakov, Y., 2006. Sources of $\mathrm{CO}_{2}$ efflux from soil and review of partitioning methods. Soil Biol. Biochem., 38, 425-448. 
Meisner, A., Bååth, E., Rousk, J., 2013. Microbial growth responses upon rewetting soil dried for four days or one year. Soil Biol. Biochem., 66, 188-192.

Meisner, A., Rousk, J., Bååth, E., 2015. Prolonged drought changes the bacterial growth response to rewetting. Soil Biol. Biochem., 88, 314-322.

Molaei, A., Lakzian, A., Haghnia, G., Astaraei, A., RasouliSadaghiani, M., Teresa Ceccherini M., Datta, R., 2017. Assessment of some cultural experimental methods to study the effects of antibiotics on microbial activities in a soil: An incubation study. PLoS ONE, 12, 7, e0180663.

Moyano, F.E., Vasilyeva, N., Bouckaert, L., Cook, F., Craine, J., Curiel Yuste, J., Don, D., Epron, D., Formanek, P., Franzluebbers, A., Ilstedt, U., Kätterer, K., Orchard, V., Reichstein, M., Rey, A., Ruamps, L., Subke, J.-A., Thomsen, I.K., Chenu, C., 2012. The moisture response of soil heterotrophic respiration: interaction with soil properties. Biogeosciences, 9, 1173-1182.

Moyano, F.E., Vasilyeva, N., Lorenzo, M., 2018. Diffusion limitations and Michaelis-Menten kinetics as drivers of combined temperature and moisture effects on carbon fluxes of mineral soils. Biogeosciences, 15, 5031-5045.

OECD, 2002. Test No. 307: aerobic and anaerobic transformation in soil. In: OECD Guidelines for the Testing of Chemicals, Section 3: Degradation and Accumulation. OECD, ISBN: 9789264070509,17 p.

Pavlů, L., Kodešová, R., Fér, M., Nikodem, A., Němec, F., Prokeš, R., 2021. The impact of various mulch types on soil properties controlling water regime of the Haplic Fluvisol. Soil Till. Res., 205, 104748.

R Development Core Team, 2015. R. a language and environment for statistical computing. $\mathrm{R}$ foundation for Statistical Computing. (http.//www.R-project.org).

Rhoades, J.D., 1996. Salinity, electrical conductivity and total dissolved solids. In: Sparks, D.L., Page, A.L., Helmke, P.A., Loeppert, R.H., Soltanpour, P.N., Tabatabai, M.A., Johnston, C.T., Sumner, M.E. (Eds): Methods of Soil Analysis. Part 3. Chemical Methods. Soil Science Society of America, Inc., Madison, pp. 417-435.

Schaffer, M., Licha, T., 2015. A framework for assessing the retardation of organic molecules in groundwater: implications of the species distribution for the sorption influenced transport. Sci. Total Environ., 524-525, 187-194.

Schaufler, G., Kitzler, B., Schindlbacher, A., Skiba, U., Sutton, M.A., Zechmeister-Boltenstern, S., 2010. Greenhouse gas emissions from European soils under different land use. effects of soil moisture and temperature. Eur. J. Soil Sci., 61, 683-696.

Schmidtová, Z., Kodešová, R., Grabicová, K., Kočárek, M., Fér, M., Švecová, H., Klement, A., Nikodem, A., Grabic, R.,
2020. Competitive and synergic sorption of carbamazepine, citalopram, clindamycin, fexofenadine, irbesartan and sulfamethoxazole in seven soils. J. Contam. Hydrol., 234, 103680.

Shen, G., Zhang, Y., Hu, S., Zhang, H., Yuan, Z., Zhang, W., 2018. Adsorption and degradation of sulfadiazine and sulfamethoxazole in an agricultural soil system under an anaerobic condition: Kinetics and environmental risks. Chemosphere, 194, 266-274.

Skjemstad, J., Baldock, J.A., 2008. Total and organic carbon. In: Carter, M. (Ed): Soil Sampling and Methods of Analysis, (2nd Edition), Boca Raton, FL, USA. Soil Science Society of Canada, CRC Press, pp. 225-238.

Srinivasan, P., Sarmah, A.K., 2014. Dissipation of sulfamethoxazole in pasture soils as affected by soil and environmental factors. Sci. Total Environ., 479-480, 284-291.

Thelusmond, J.R., Strathmann, T.J., Cupples, A.M., 2019. Carbamazepine, triclocarban and triclosan biodegradation and the phylotypes and functional genes associated with xenobiotic degradation in four agricultural soils. Sci. Total Environ., 657, 1138-1149.

WRB, 2015. World Reference Base for Soil Resources 2014, update 2015 International soil classification system for naming soils and creating legends for soil maps. World Soil Resources Reports No. 106. FAO, Rome.

$\mathrm{Xu}$, L., Baldocchi, D.D., Tang, J., 2004. How soil moisture, rain pulses, and growth alter the response of ecosystem respiration to temperature. Global Biogeoch. Cy., 18, GB4002.

Yuste, J.C., Baldocchi, D.D., Gershenson, A., Goldstein, A., 2007. Microbial soil respiration and its dependency on carbon inputs, soil temperature and moisture. Glob. Change Biol., 13, 1-18.

Verlicchi, P., Zambello, E., 2015. Pharmaceuticals and personal care products in untreated and treated sewage sludge: occurrence and environmental risk in the case of application on soil - a critical review. Sci. Total Environ., 538, 750-767.

Zhang, Y., Hu, S., Zhang, H., Shen, G., Yuan, Z., Zhang, W., 2017. Degradation kinetics and mechanism of sulfadiazine and sulfamethoxazole in an agricultural soil system with manure application. Sci. Total Environ., 607-608, 1348-1356.

Zhi, D., Yang, D., Zheng, Y., Yang, Y., He, Y., Luo, L., Zhou, Y., 2019. Current progress in the adsorption, transport and biodegradation of antibiotics in soil. J. Environ. Manage., 251, 109598.

Zhong, Y., Yan, W., Zong, Y., Shangguan, Z., 2016. Biotic and abiotic controls on the diel and seasonal variations in soil respiration and its components in a wheat field under longterm nitrogen fertilization. Field Crop. Res., 199, 1-9.

Received 22 June 2020 Accepted 20 July 2020 